\title{
GMR
}

\section{Meta-analysis of the $I L-10$ promoter polymorphisms and pediatric asthma susceptibility}

\author{
Z.Y. Huang*, B.J. Cheng*, Y. Wan and C. Zhou \\ Department of Pediatrics, No. 2 Hospital of Changzhou, Jiangsu, China \\ *These authors contributed equally to this study. \\ Corresponding author: Z.Y. Huang \\ E-mail: hzy982@126.com
}

Genet. Mol. Res. 15 (2): gmr. 15028320

Received December 21, 2015

Accepted March 8, 2016

Published June 3, 2016

DOI http://dx.doi.org/10.4238/gmr.15028320

\begin{abstract}
The results of previous epidemiological studies exploring the relationship between interleukin-10 (IL-10) promoter polymorphisms and susceptibility to pediatric asthma are not consistent. Therefore, we have performed a systematic review and meta-analysis to provide a more convincing conclusion. Odds ratios (OR) with their $95 \%$ confidence intervals (CIs) were used to evaluate the strength of association between the $I L-10$ promoter polymorphisms and susceptibility to pediatric asthma. Publication bias was examined by Begg's funnel plots and the Egger test. A detailed literature search based on stringent parameters yielded sixteen relevant studies, comprising 2494 cases and 2160 controls. The overall population showed no significant association between the $I L-10-1082 \mathrm{G} / \mathrm{A}$ polymorphism and pediatric asthma risk in any of the genetic models (dominant model: $\mathrm{OR}=1.583,95 \% \mathrm{CI}=0.614-4.076, \mathrm{P}=0.342$; allelic model: $\mathrm{OR}=1.214,95 \% \mathrm{CI}=0.748-1.971, \mathrm{P}=0.433$; additive model: $\mathrm{OR}=2.240,95 \% \mathrm{CI}=0.950-5.277, \mathrm{P}=0.065$; recessive model: $\mathrm{OR}=1.435,95 \% \mathrm{CI}=0.659-3.128, \mathrm{P}=0.363$ ). Subgroup analyses revealed a significant association between different ethnicity
\end{abstract}


and atopic status subgroups. However, there was no evidence of a significant association between the other two polymorphisms (-819C/ $\mathrm{T}$ and $-592 \mathrm{C} / \mathrm{A}$ ) and pediatric asthma in our study. No significant publication bias was observed in this meta-analysis. The results of this study indicate that the $I L-10-1082 \mathrm{G} / \mathrm{A}$ polymorphism might be a risk factor for asthma in children. However, because of the small sample size included in the subgroup analyses, the results should be interpreted with caution.

Key words: Interleukin-10; Polymorphism; Pediatric asthma; Meta-analysis

\section{INTRODUCTION}

Pediatric asthma is one of the most common diseases affecting children worldwide (Eijkemans et al., 2008). According to the World Health Organization (WHO), approximately 235 million people suffered from asthma worldwide, with 157,000 requiring urgent medical aid, during 2007 (Bilal et al., 2016). The onset of asthma onset occurs before the age of 12 (years) in over half the cases. The past 20 years have seen a significant increase in the prevalence of asthma in children (Tang et al., 2015). The pathogenesis of asthma is related to multiple risk factors including environmental factors such as vehicular pollution, and genetic factors such as polymorphisms in the interleukin (IL)-4 and ORMDL3 genes (Favarato et al., 2014; Tang et al., 2014; Zhai et al., 2015).

A number of studies have reported that IL-10 plays an important role in the pathogenesis of asthma (Zheng et al., 2010). IL-10 is an important anti-inflammatory factor secreted by Th2 cells, monocytes/macrophages, and B lymphocytes. IL-10 stimulates the proliferation and activation of B lymphocytes, in addition to inhibiting the synthesis of TNF- $\gamma$ and IL-2 (Del Prete et al., 1993). Studies have also suggested that IL-10 could reduce allergic inflammation by inhibiting the production of pro-inflammatory cytokines.

$I L-10$ is located at chromosome 1q31-q32, a region associated with asthma susceptibility. Previous studies assessing the association between $I L-10$ promoter polymorphisms and susceptibility to asthma have yielded inconsistent and inconclusive results. A majority of these studies have focused on three single nucleotide polymorphisms in the promoter region: $-1082 \mathrm{G} / \mathrm{A}(\mathrm{rs} 1800896$ or $-1087 \mathrm{G} / \mathrm{A}$ or $-1117 \mathrm{G} / \mathrm{A}),-819 \mathrm{C} / \mathrm{T}$ (rs1800871 or $\mathrm{rs} 3021097$ or $-892 \mathrm{C} / \mathrm{T}$ or $-854 \mathrm{C} / \mathrm{T}$ or $-824 \mathrm{C} / \mathrm{T}$ ), and $-592 \mathrm{C} / \mathrm{A}(\mathrm{rs} 1800872$ or $-571 \mathrm{C} / \mathrm{A}$ or $-597 \mathrm{C} / \mathrm{A}$ or $-627 \mathrm{C} / \mathrm{A}$ ) (Lyon et al., 2004; Kube et al., 2007; Zhan and Chen, 2013). The -592C/A polymorphism in the $I L-10$ promoter has been reported to influence the expression of IL-10 in the serum, which suggests the importance of polymorphisms in the $I L-10$ promoter region in the pathogenesis of asthma (Ji et al., 2013). Previous studies have indicated that these polymorphisms might be associated with increased susceptibility to asthma (Movahedi et al., 2008; Zedan et al., 2008). For instance, Zedan et al. (2008) reported that the GG genotype at the $I L-10-1082$ region could be a contributing factor for the increased susceptibility to, and severity of, childhood asthma in Egypt. In contrast, Hussein et al. (2011) reported that the -1082 AA genotype increased asthma risk in Egyptian children. Xu et al. (2014) reported a similar finding in a Chinese population. Moreover, Movahedi et al. (2008) reported a significant association between the $I L-10$ 
$-1082 \mathrm{G} / \mathrm{A},-819 \mathrm{C} / \mathrm{T}$, and $-592 \mathrm{C} / \mathrm{A}$ polymorphisms and pediatric asthma in Iran. In contrast, other studies have reported no significant association between these variants and the risk of pediatric asthma; for example, Kim et al. (2011) revealed that the $I L-10-1082 \mathrm{G} / \mathrm{A},-819 \mathrm{C} /$ $\mathrm{T}$, and $-592 \mathrm{C} / \mathrm{A}$ polymorphisms were not associated with pediatric asthma in a Korean population, which was consistent with the results obtained by Li et al. (2007).

The results of previous meta-analyses exploring the association between these three polymorphisms in the $I L-10$ promoter region and asthma susceptibility are not consistent (Nie et al., 2012; Hyun et al., 2013; Zheng et al., 2014). Both Nie et al. (2012) and Zheng et al. (2014) concluded that the $I L-10-1082 \mathrm{G} / \mathrm{A}$ and $-592 \mathrm{C} / \mathrm{A}$ (and not the $-819 \mathrm{C} /$ T) polymorphisms were significantly associated with asthma susceptibility. However, the former did not analyze these relationships in children, and the latter reported no associations between these polymorphisms and pediatric asthma in an Asian population, despite stratifying the data by age. However, it should be noted that the subgroup analysis by age conducted in this meta-analysis was limited to Asian children; therefore, a relatively low number of studies was included ( 2 studies reporting on the $-1082 \mathrm{G} / \mathrm{A}, 5$ on $-592 \mathrm{C} / \mathrm{A}$, and none reporting the $-819 \mathrm{C} / \mathrm{T}$ polymorphism). Moreover, the data extraction process employed by some of the included studies was faulty. For example, Daley et al. (2009) did not examine asthma in children. Hyun et al. (2013) reported an association between the $I L-10-1082 \mathrm{G} / \mathrm{A}$, and not the $-819 \mathrm{C} / \mathrm{T}$ and $-592 \mathrm{C} / \mathrm{A}$, polymorphism and asthma in an East Asian population; however, none of these polymorphisms were reported to be associated with asthma susceptibility in children (only four of the included studies focused on children).

This meta-analysis was conducted in view of the previous meta-analyses with the relatively small sample size and other limitations to clarify the relationship between the $I L-10$ promoter polymorphisms and pediatric asthma.

\section{MATERIAL AND METHODS}

\section{Study selection}

This meta-analysis was performed according to the guidelines of the preferred reporting items for systematic reviews and meta-analyses (PRISMA) (Moher et al., 2009). An exhaustive search of the electronic databases PubMed, EMBase, Chinese biomedical database, and China national knowledge infrastructure was performed to extract relevant studies published prior to March 1, 2015. The following combinations of keywords and/or medical subject headings terms were used for study extraction: "IL-10" or "interleukin-10"; "polymorphism" or "variant" or "gene" or "mutation"; and "asthma" or "asthmatic". The studies were retrieved by two independent researchers (Huang and Zhang). A further manual search of the references of all extracted studies was conducted to retrieve additional studies and data. No language restriction was set for this study.

\section{Inclusion and exclusion criteria}

The following inclusion criteria were set for study inclusion: 1) case-control studies (study design); 2) studies exploring the relationship between $I L-10$ polymorphism and pediatric asthma risk; and 3) studies containing sufficient data to calculate the odds ratios 
(ORs) and 95\% confidence intervals (CIs). Studies were excluded based on the following criteria: 1) studies designed on the basis of families or sibling pairs; 2) reviews or abstracts; and 3) studies that did not report the genotype or allele frequencies, making it impossible to calculate the OR. The most comprehensive study was selected when the same population was the focus of multiple studies. The corresponding authors were contacted by email for clarifications regarding their studies.

\section{Data extraction}

The baseline information, such as the first author; year of publication; age, country, and ethnicity of the study population; genotyping method; atopic status; number of cases and controls; and genotype and allele frequencies, was extracted independently from each study by two researchers (Huang and Cheng). Any discrepancy was resolved by a discussion between the researchers. Some data were extracted from previous meta-analyses. Studies with obviously incorrect original data, for which corresponding authors did not respond satisfactorily to our queries, were deleted during the selection process.

\section{Quality assessment}

The quality of each included study was assessed using the Newcastle-Ottawa scale (NOS) (Huang et al., 2015). The NOS score ranged from 0 (worst) to 9 (best) stars. Articles with NOS scores $>6$ stars were deemed to be of a high quality. Case-control studies were also assessed on a scale of 0-9 based on the subject selection, comparability, and outcome; studies with scores $>7$ were deemed to be of high quality.

\section{Statistical analyses}

The Hardy-Weinberg equilibrium (HWE) of the $I L-10$ genotype distributions in the control groups was determined using the Fisher exact test. The strength of the association between the $I L-10$ promoter polymorphisms and risk of pediatric asthma was evaluated using the pooled OR with its $95 \% \mathrm{CI}$.

Four comparative genetic models were used to calculate the pooled results: the dominant (-1082G/A: AA+GA vs GG; -891C/T: TT+TC vs CC; -592C/A: AA+AC vs CC), recessive (-1082G/A: AA vs GA+GG; -891C/T: TT vs CT+CC; -592C/A: AA vs CA+CC), allelic (-1082G/A: A vs G; -891C/T: T vs C; -592C/A: A vs C), and additive (-1082G/A: AA vs GG; -891C/T: TT vs CC; -592C/A: AA vs CC) models.

The heterogeneity between studies was assessed by the chi-squared Q-test, and the heterogeneity among studies was tested by the $I^{2}$ statistic. In case of a statistically significant heterogeneity ( $\mathrm{P}<0.01$ or $I^{2}>50 \%$ ), a random-effects model (DerSimonian-Laird method) was used to estimate the pooled OR. Otherwise, a fixed-effects model (Mantel-Haenszel method) was adopted (DerSimonian and Kacker, 2007). The sources of heterogeneity were identified by performing analyses based on the ethnicity and atopic status. The stability of this meta-analysis was assessed by a one-way sensitivity analysis. Publication bias was detected by a Begg's funnel plot and the Egger test.

All statistical analyses were performed using STATA 12.0 (Stata Corp LP, College Station, TX, USA). P values $<0.05$ were considered statistically significant. 


\section{RESULTS}

\section{Study characteristics}

Figure 1 outlines the selection process of this literature review. Briefly, the initial search identified 211 articles, of which 168 were excluded based on a review of the title and abstract. The remaining 43 articles were retrieved for a detailed evaluation, which in turn led to the exclusion of 27 articles. The studies were excluded for the following reasons: reviews $(\mathrm{N}=5)$, duplicated data $(\mathrm{N}=3)$, non-case-control study $(\mathrm{N}=5)$, no useful data $(\mathrm{N}=2)$, irrelevant to pediatric asthma $(\mathrm{N}=12)$.

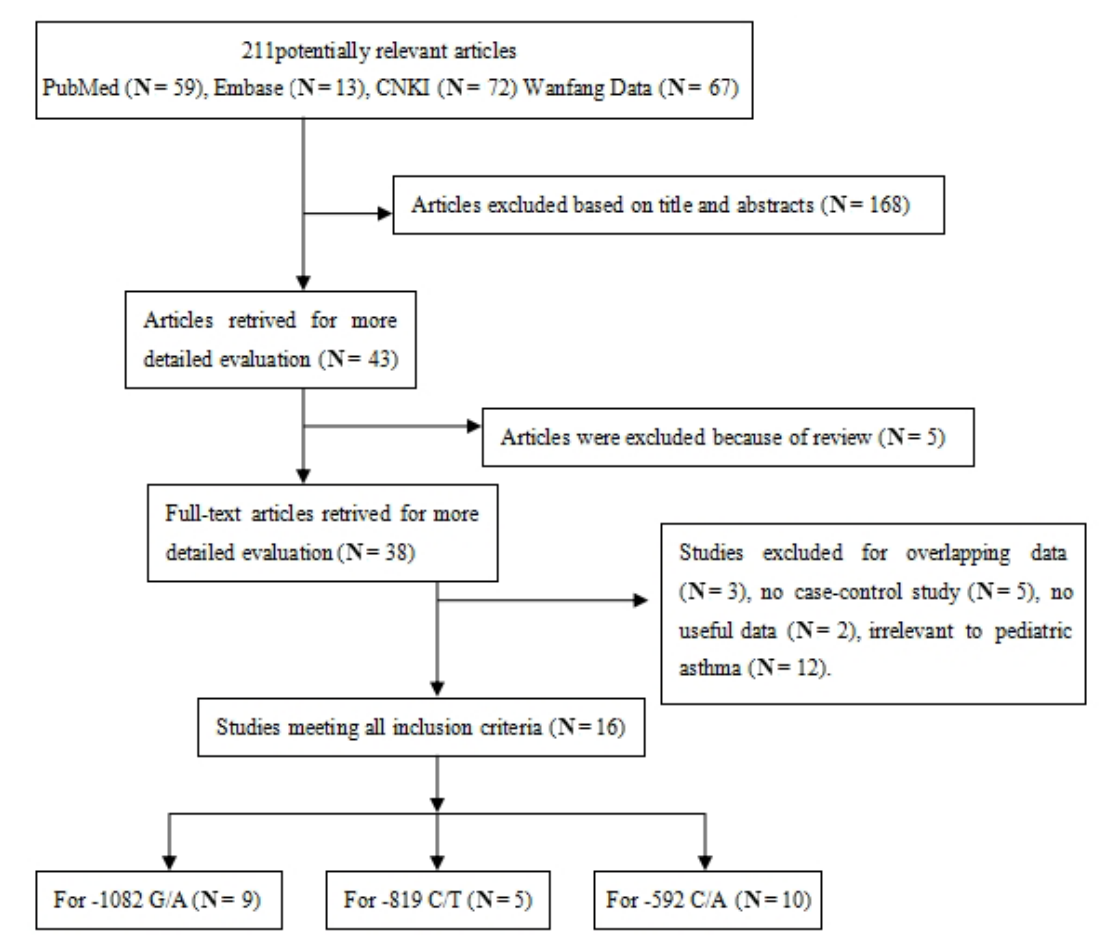

Figure 1. Flow diagram depicting the study selection process.

Finally, a total of 16 case-control studies comprising 2494 cases and 2160 controls were included in this meta-analysis to evaluate the association between $I L-10$ promoter polymorphisms and the risk of pediatric asthma (Zhang et al., 2002; Schubert et al., 2006; Li et al., 2006, 2007; Movahedi et al., 2008; Zedan et al., 2008; Undarmaa et al., 2010; Hussein et al., 2011; Kim et al., 2011; Wei et al., 2011; Xie, 2012; Ji et al., 2013; Smolnikova et al., 2013; Tan et al., 2013; Hussein et al., 2014; Xu et al., 2014). Eleven of the studies were performed in an Asian population, and three and two of the remaining studies were conducted in people of African and Caucasian descent, respectively. Two of the included studies (Hussein et al., 2011; Kim et al., 2011) separated the population based on the atopic status (atopic and nonatopic asthma) and the data was independently extracted. Therefore, each study was deemed 
as two independent studies in the subgroup analysis based on atopic status. The sample sizes ranged from 56 to 661 . The study quality was assessed by the NOS score, which ranged from four to seven for the individual studies. The studies used several genotyping methods, including polymerase chain reaction-restriction fragment length polymorphism (PCR-RFLP), matrix-assisted laser desorption ionization-time of flight-mass spectrometry (MALDI-TOFMS), amplification refractory mutation system-PCR (ARMS-PCR); TaqMan allele specific amplification (TaqMan-ASA), sequence specific primer-PCR (SSP-PCR), Sequenom MassARRAY, and DNA sequencing.

The distribution of genotypes in the controls in 11 studies was consistent with the HWE. The characteristics of the individual studies included in this meta-analysis are listed in Table 1. The genotype and allele frequencies reported in each study are listed in Tables 2, 3, and 4.

\begin{tabular}{|c|c|c|c|c|c|c|c|c|c|c|}
\hline First author & Year & Country & Ethnicity & Atopic status & $\begin{array}{c}\begin{array}{c}\text { Sample size } \\
\text { (Case/Control) }\end{array} \\
\end{array}$ & \begin{tabular}{|l} 
Diagnosis of asthma \\
\end{tabular} & \begin{tabular}{|l} 
Genotyping method \\
\end{tabular} & Polymorphic sites & $\begin{array}{l}\mathrm{HWE} \\
(\mathrm{Y} / \mathrm{N})\end{array}$ & NOS \\
\hline Zhang JL & 2002 & China & Asian & Not available & $168 / 53$ & $\begin{array}{l}\text { National guideline of prevention and } \\
\text { management of children asthma (China) }\end{array}$ & \begin{tabular}{|l} 
PCR-RFLP \\
\end{tabular} & $-1082,-819$ & 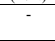 & 6 \\
\hline Li HL & 2006 & China & Asian & Not available & $50 / 36$ & $\begin{array}{l}\text { Guidelines of prevention and treatment of } \\
\text { bronchial asthma in children (China, 2004) }\end{array}$ & PCR-RFLP & -592 & $\mathrm{Y}$ & 4 \\
\hline Schubert K & 2006 & Germany & Caucasian & Not available & $231 / 273$ & $\begin{array}{l}\text { Symptoms and medical history } \\
\end{array}$ & DNA sequencing and RFLP & -592 & $\mathrm{Y}$ & 5 \\
\hline Li ZF & 2007 & China & Asian & Non-atopic asthma & $30 / 26$ & $\begin{array}{l}\text { Guidelines of prevention and treatment of } \\
\text { bronchial asthma in children (China, 2004) }\end{array}$ & PCR-SSP & $-1082,-819,-592$ & $\mathrm{Y}$ & 5 \\
\hline Zedan $\mathrm{M}$ & 2008 & Egypt & African & Atopic asthma & $69 / 98$ & $\begin{array}{ll}\text { GINA } \\
\end{array}$ & PCR-SSP & -1082 & $\mathrm{~N}$ & 6 \\
\hline Movahedi M & 2008 & Iran & Asian & Not available & $59 / 140$ & $\begin{array}{l}\text { National Asthma Education and Prevention } \\
\text { program (Expert Panel Report-3) guidelines }\end{array}$ & \begin{tabular}{|l} 
PCR-SSP \\
\end{tabular} & $-1082,-819,-592$ & $\mathrm{~N}$ & 7 \\
\hline Undarmaa S & 2010 & Japan & Asian & Atopic asthma & $325 / 336$ & $\begin{array}{l}\text { ATS guidelines } \\
\end{array}$ & TaqMan-ASA & -592 & $\mathrm{Y}$ & 6 \\
\hline Hussein YM & 2011 & Egypt & African & Mixed* & $220 / 110$ & \begin{tabular}{|l|l} 
ATS guidelines \\
\end{tabular} & ARMS-PCR & -1082 & $\mathrm{Y}$ & 6 \\
\hline $\mathrm{Kim} \mathrm{KW}$ & 2011 & Korea & Asian & Mixed $^{*}$ & $333 / 248$ & \begin{tabular}{|l} 
ATS guidelines \\
\end{tabular} & \begin{tabular}{|l|} 
PCR-RFLP \\
\end{tabular} & $-1082,-819,-592$ & $\mathrm{Y}$ & 6 \\
\hline Wei B & 2011 & China & Asian & Not available & $186 / 198$ & $\begin{array}{l}\text { Guidelines of prevention and treatment of } \\
\text { bronchial asthma in children (China, 2004) }\end{array}$ & \begin{tabular}{|l|} 
PCR-RFLP \\
\end{tabular} & -592 & $\mathrm{Y}$ & 5 \\
\hline Xie Q & 2012 & China & Asian & Not available & $110 / 63$ & $\begin{array}{l}\text { Symptoms and bronchial challenge or } \\
\text { bronchodilator test }\end{array}$ & \begin{tabular}{|l|} 
PCR-RFLP \\
\end{tabular} & -592 & $\mathrm{~N}$ & 4 \\
\hline $\mathrm{Ji}$ JF & 2013 & China & Asian & Not available & $92 / 92$ & $\begin{array}{l}\text { Guidelines of prevention and treatment of } \\
\text { bronchial asthma in children (China, 2008) }\end{array}$ & \begin{tabular}{|l} 
PCR-RFLP \\
\end{tabular} & -592 & $\mathrm{Y}$ & 7 \\
\hline Smolnikova MV & 2013 & Russia & Caucasian & Atopic asthma & $64 / 50$ & GINA & PCR-RFLP & -592 & $\mathrm{Y}$ & 7 \\
\hline Tan JY & 2013 & China & Asian & Not available & $157 / 198$ & $\begin{array}{l}\text { Guidelines of prevention and treatment of } \\
\text { bronchial asthma (Chinese Medical } \\
\text { Association, 2008) }\end{array}$ & MALDI-TOF- MS & -1082 & $\mathrm{Y}$ & 6 \\
\hline Hussein YM & 2014 & Egypt & African & Atopic asthma & $200 / 50$ & ATS guidelines & ARMS-PCR & -1082 & $\mathrm{Y}$ & 6 \\
\hline Xu JX & 2014 & China & Asian & Not available & $200 / 189$ & $\begin{array}{l}\text { Guidelines of prevention and treatment of } \\
\text { bronchial asthma (Chinese Medical } \\
\text { Association, 2008) }\end{array}$ & MassARRAY & $-1082,-819$ & $\mathrm{~N}$ & 4 \\
\hline
\end{tabular}

*Atopic and non-atopic data was independently extracted Y: yes; N: no HWE, Hardy-Weinberg equilibrium; NOS, Newcastle-Ottawa scale; PCR-RFLP, polymerase chain reaction-restriction fragment length polymorphism; ARMSPCR, amplification refractory mutation system-PCR; ASA, allele-specific amplification; SSP, sequence specific primer; MALDI-TOF-MS, matrix assisted laser desorption ionization-time of flight-mass spectrometry; ATS, American thoracic society; GINA, Global initiative for asthma.

Table 2. Distribution of IL-10 -1082 G/A genotypes and alleles among patients and controls.

\begin{tabular}{|c|c|c|c|c|c|c|c|c|c|c|c|c|}
\hline \multirow[t]{2}{*}{ Author } & \multirow[t]{2}{*}{ Year } & \multirow[t]{2}{*}{ Atopic status } & \multicolumn{3}{|c|}{ Cases } & \multicolumn{3}{|c|}{ Controls } & \multicolumn{2}{|c|}{ Cases } & \multicolumn{2}{|c|}{ Controls } \\
\hline & & & GG & GA & AA & GG & GA & $\mathrm{AA}$ & $\mathrm{G}$ & $\mathrm{A}$ & $\mathrm{G}$ & $\mathrm{A}$ \\
\hline Zhang JL & 2002 & Not available & - & - & - & - & - & - & 37 & 299 & 12 & 94 \\
\hline $\mathrm{Li}$ ZF & 2007 & Non-atopic & 2 & 8 & 20 & 3 & 7 & 16 & 12 & 48 & 13 & 39 \\
\hline Movahedi M & 2008 & Not available & 0 & 59 & 0 & 12 & 75 & 53 & 59 & 59 & 99 & 181 \\
\hline Zedan M & 2008 & Atopic & 19 & 39 & 11 & 5 & 85 & 8 & 77 & 61 & 95 & 101 \\
\hline \multirow[t]{3}{*}{ Hussein YM } & \multirow[t]{3}{*}{2011} & Mixed & 48 & 90 & 82 & 33 & 54 & 23 & 186 & 254 & 120 & 100 \\
\hline & & Atopic & 24 & 44 & 42 & 33 & 54 & 23 & 92 & 128 & 120 & 100 \\
\hline & & Non-atopic & 24 & 46 & 40 & 33 & 54 & 23 & 94 & 126 & 120 & 100 \\
\hline \multirow[t]{3}{*}{ Kim KW } & \multirow[t]{3}{*}{2011} & Mixed & 2 & 40 & 291 & 3 & 30 & 215 & 44 & 622 & 36 & 460 \\
\hline & & Atopic & 1 & 33 & 244 & 3 & 30 & 215 & 35 & 521 & 36 & 460 \\
\hline & & Non-atopic & 1 & 7 & 47 & 3 & 30 & 215 & 9 & 101 & 36 & 460 \\
\hline Tan JY & 2013 & Not available & 0 & 23 & 134 & 0 & 16 & 182 & 23 & 291 & 16 & 380 \\
\hline Hussein YM & 2014 & Atopic & 39 & 86 & 75 & 17 & 25 & 8 & 164 & 236 & 59 & 41 \\
\hline Xu JX & 2014 & Not available & 0 & 39 & 161 & 8 & 108 & 73 & 39 & 361 & 124 & 254 \\
\hline
\end{tabular}


Table 3. Distribution of $I L-10-819 \mathrm{C} / \mathrm{T}$ genotypes and alleles among patients and controls.

\begin{tabular}{|c|c|c|c|c|c|c|c|c|c|c|c|c|}
\hline \multirow{2}{*}{ Author } & \multirow{2}{*}{ Year } & \multirow{2}{*}{ Atopic status } & \multicolumn{3}{|c|}{ Cases } & \multicolumn{3}{|c|}{ Controls } & \multicolumn{2}{|c|}{ Cases } & \multicolumn{2}{|c|}{ Controls } \\
\hline & & & $\mathrm{CC}$ & CT & TT & $\mathrm{CC}$ & CT & TT & $\mathrm{C}$ & $\mathrm{T}$ & $\mathrm{C}$ & $\mathrm{T}$ \\
\hline Zhang JL & 2002 & Not available & - & - & - & - & - & - & 126 & 210 & 42 & 64 \\
\hline $\mathrm{Li} Z \mathrm{ZF}$ & 2007 & Non-atopic & 6 & 17 & 7 & 7 & 9 & 10 & 29 & 31 & 23 & 29 \\
\hline Movahedi M & 2008 & Not available & 2 & 57 & 0 & 71 & 57 & 12 & 61 & 57 & 199 & 81 \\
\hline Kim KW & 2011 & Mixed & 40 & 138 & 155 & 27 & 108 & 113 & 218 & 448 & 162 & 334 \\
\hline Xu JX & 2014 & Not available & 20 & 87 & 93 & 18 & 77 & 94 & 127 & 273 & 113 & 265 \\
\hline
\end{tabular}

Table 4. Distribution of $I L-10-592 \mathrm{C} / \mathrm{A}$ genotypes and alleles among patients and controls.

\begin{tabular}{|c|c|c|c|c|c|c|c|c|c|c|c|c|}
\hline \multirow[t]{2}{*}{ Author } & \multirow[t]{2}{*}{ Year } & \multirow[t]{2}{*}{ Atopic status } & \multicolumn{3}{|c|}{ Cases } & \multicolumn{3}{|c|}{ Controls } & \multicolumn{2}{|c|}{ Cases } & \multicolumn{2}{|c|}{ Controls } \\
\hline & & & $\mathrm{CC}$ & CA & $\mathrm{AA}$ & $\mathrm{CC}$ & $\mathrm{CA}$ & $\mathrm{AA}$ & $\mathrm{C}$ & $\mathrm{A}$ & $\mathrm{C}$ & $\mathrm{A}$ \\
\hline Li HL & 2006 & Not available & 6 & 24 & 20 & 3 & 17 & 16 & 36 & 64 & 23 & 49 \\
\hline Schubert K & 2006 & Not available & 131 & 86 & 14 & 145 & 109 & 19 & 348 & 114 & 399 & 147 \\
\hline $\mathrm{Li} Z \mathrm{ZF}$ & 2007 & Non-atopic & 6 & 17 & 7 & 7 & 9 & 10 & 29 & 31 & 23 & 29 \\
\hline Movahedi M & 2008 & Not available & 1 & 58 & 0 & 71 & 57 & 12 & 60 & 58 & 199 & 81 \\
\hline Undarmaa S & 2010 & Atopic & 30 & 141 & 154 & 39 & 151 & 146 & 201 & 449 & 229 & 443 \\
\hline \multirow[t]{3}{*}{ Kim KW } & \multirow[t]{3}{*}{2011} & Mixed & 44 & 143 & 146 & 31 & 106 & 111 & 231 & 435 & 168 & 328 \\
\hline & & Atopic & 34 & 124 & 120 & 31 & 106 & 111 & 192 & 364 & 168 & 328 \\
\hline & & Non-atopic & 10 & 19 & 26 & 31 & 106 & 111 & 39 & 71 & 168 & 328 \\
\hline Wei B & 2011 & Not available & 22 & 89 & 75 & 16 & 99 & 83 & 133 & 239 & 131 & 265 \\
\hline Xie Q & 2012 & Not available & 9 & 78 & 23 & 2 & 38 & 23 & 96 & 124 & 42 & 84 \\
\hline Ji JF & 2013 & Not available & 8 & 32 & 52 & 16 & 44 & 32 & 48 & 136 & 76 & 108 \\
\hline Smolnikova MV & 2013 & Atopic & 40 & 19 & 5 & 37 & 13 & 0 & 99 & 29 & 87 & 13 \\
\hline
\end{tabular}

\section{Quantitative analysis of the $-1082 \mathrm{G} / \mathrm{A}$ promoter polymorphism}

Nine of the extracted 16 case-control studies, comprising 1436 cases and 1112 controls, evaluated the relationship between the $I L-10-1082 \mathrm{G} / \mathrm{A}$ polymorphism and asthma risk in children. Frequency of the $-1082 \mathrm{G}$ allele was $14.72 \%$ in Asians and $43.98 \%$ in non-Asians.

Because of the significant heterogeneity between studies, the random-effects model was used to calculate the pooled OR (Table 5). The overall population showed no significant association between the $I L-10-1082 \mathrm{G} / \mathrm{A}$ polymorphism and pediatric asthma risk in any genetic model (dominant model: $\mathrm{OR}=1.583,95 \% \mathrm{CI}=0.614-4.076, \mathrm{P}=0.342$; allelic model: $\mathrm{OR}=1.214,95 \% \mathrm{CI}=0.748-1.971, \mathrm{P}=0.433$; additive model: $\mathrm{OR}=2.240,95 \% \mathrm{CI}=0.950$ 5.277, $\mathrm{P}=0.065$; recessive model: $\mathrm{OR}=1.435,95 \% \mathrm{CI}=0.659-3.128, \mathrm{P}=0.363$ ) (Figure 2).

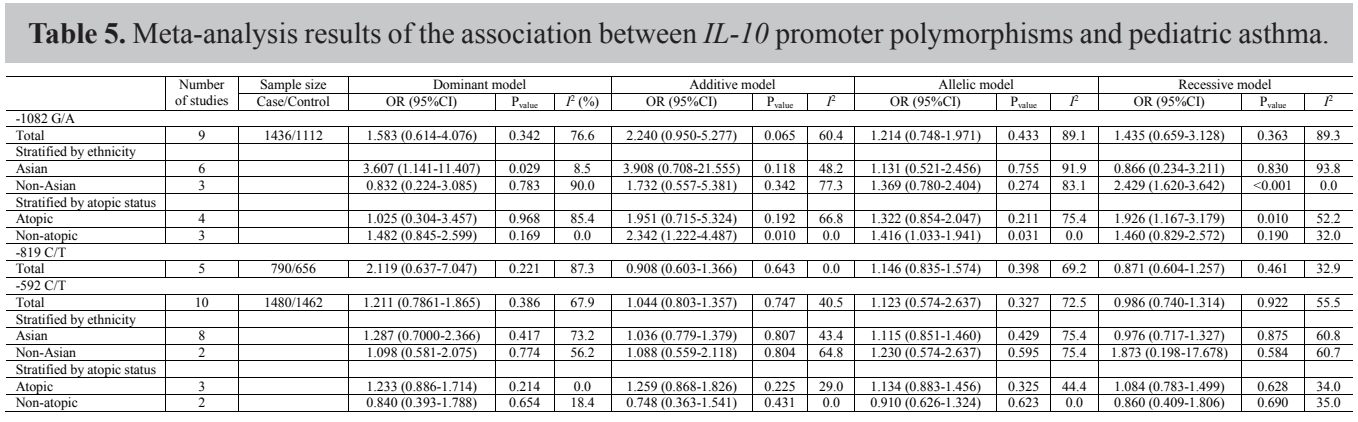




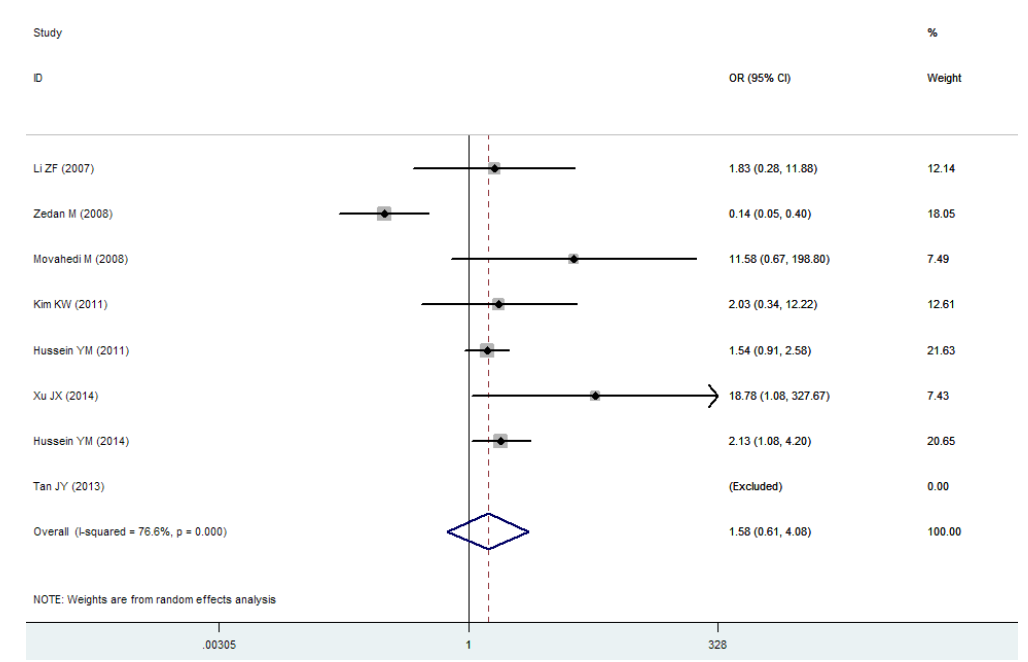

Figure 2. Forest plot of the $I L-10-1082 \mathrm{G} /$ A polymorphism under a dominant genetic model.

The subgroup analysis based on ethnicity revealed a significant association between this polymorphism in Asian populations and pediatric asthma in a dominant model $(\mathrm{OR}=3.607$, $95 \% \mathrm{CI}=1.141-11.407, \mathrm{P}=0.029)$ and non-Asian populations and pediatric asthma in a recessive model $(\mathrm{OR}=2.429,95 \% \mathrm{CI}=1.620-3.642, \mathrm{P}<0.001)$ (Figure 3A, 3B). Stratification by atopic status indicated that the $-1082 \mathrm{G} / \mathrm{A}$ polymorphism was significantly associated with non-atopic asthma in children in the additive $(\mathrm{OR}=2.342,95 \% \mathrm{CI}=1.222-4.487, \mathrm{P}=0.010)$ and allelic models $(\mathrm{OR}=1.416,95 \% \mathrm{CI}=1.033-1.941, \mathrm{P}=0.031)$, and with atopic asthma in children in the recessive model $(\mathrm{OR}=1.926,95 \% \mathrm{CI}=1.167-3.179, \mathrm{P}=0.010)$. (Figure $3 \mathrm{C}, 3 \mathrm{D})$.

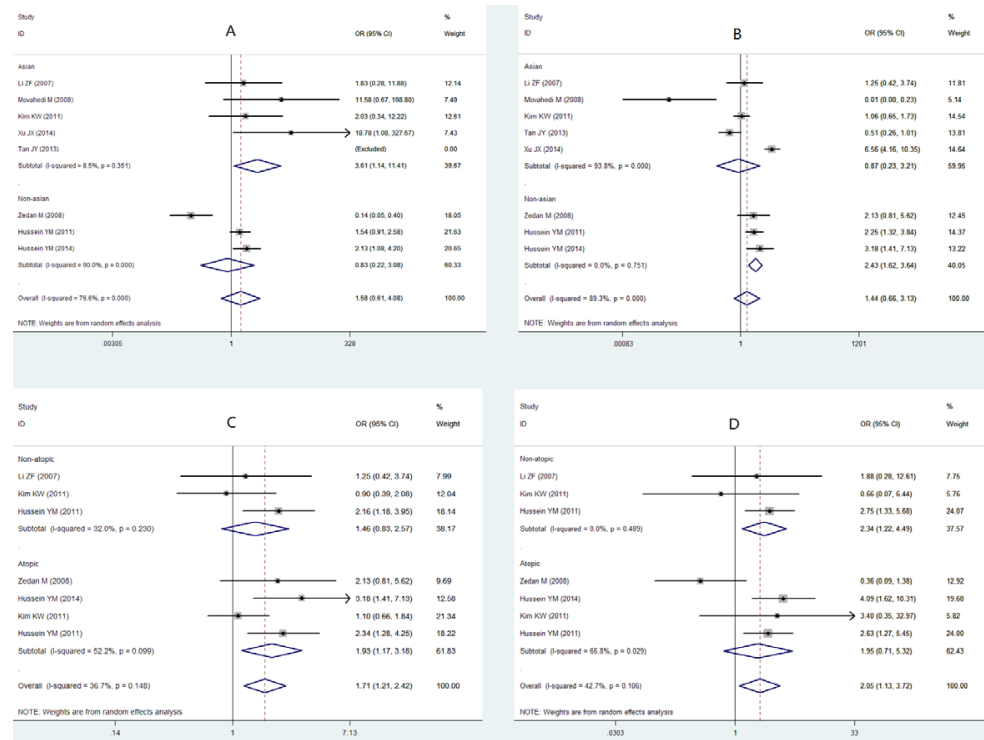

Figure 3. Forest plot of the $I L-10$-1082 G/A polymorphism stratified by A. ethnicity, in a dominant model; B. ethnicity, in a recessive model; $\mathbf{C}$. atopic status, in a recessive model; and $\mathbf{D}$. atopic status, in an additive model. 
One-way sensitivity analysis was applied to assess the stability of this meta-analysis. The pooled ORs remained unchanged when individual studies were omitted indicating that the studies did not individually influence the stability of the entire study (Figure 4A).

The shape of the funnel plot was symmetric in all of the genetic models (Figure 5A), which was also confirmed by Egger's regression test $(\mathrm{P}=0.381,0.929,0.698$, and 0.211 for the allelic, additive, dominant, and recessive models, respectively).
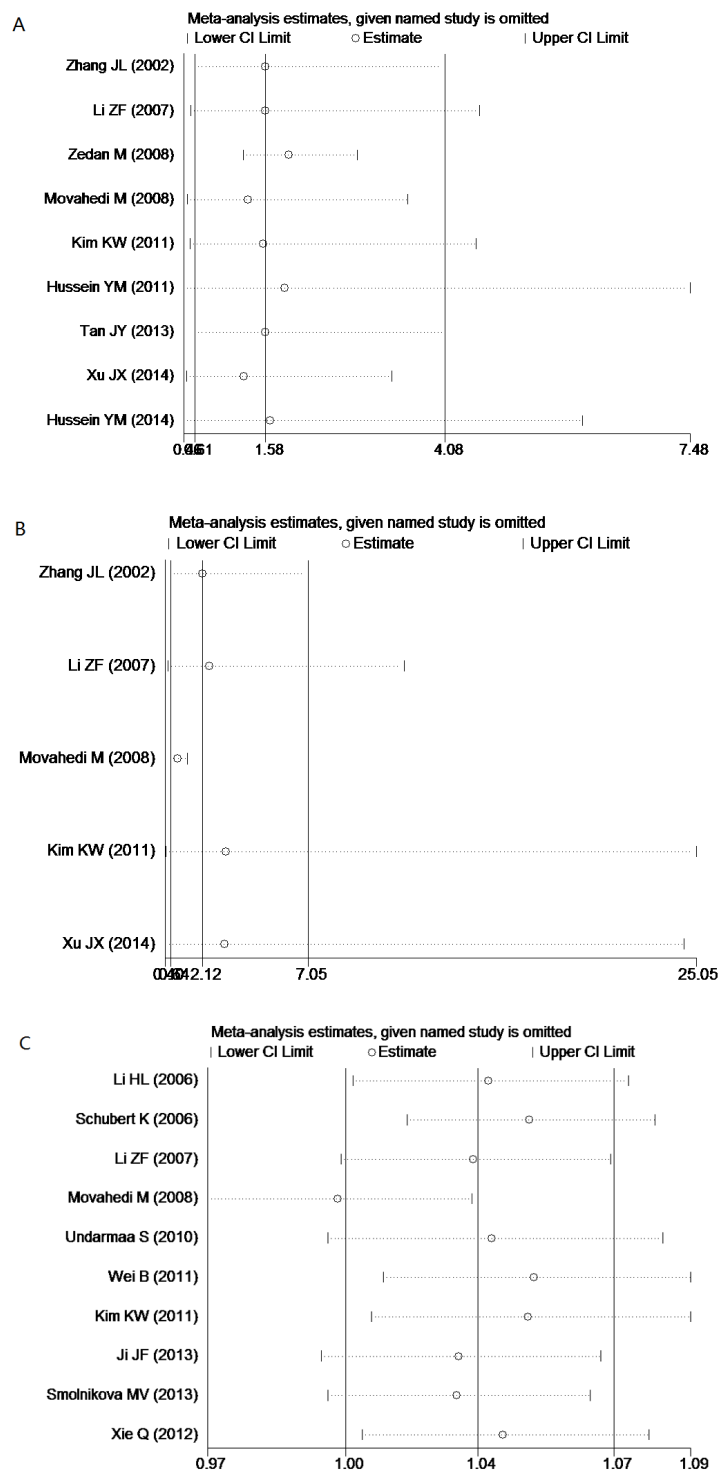

Figure 4. Analysis of the influence of the individual studies reporting on the $I L-10$ : A. $-1082 \mathrm{G} / \mathrm{A}$ B. $-819 \mathrm{C} / \mathrm{T}$, and C. $-592 \mathrm{C} / \mathrm{A}$ polymorphisms in a dominant model (open circles indicate the pooled ORs. Horizontal lines represent the $95 \%$ CIs). 

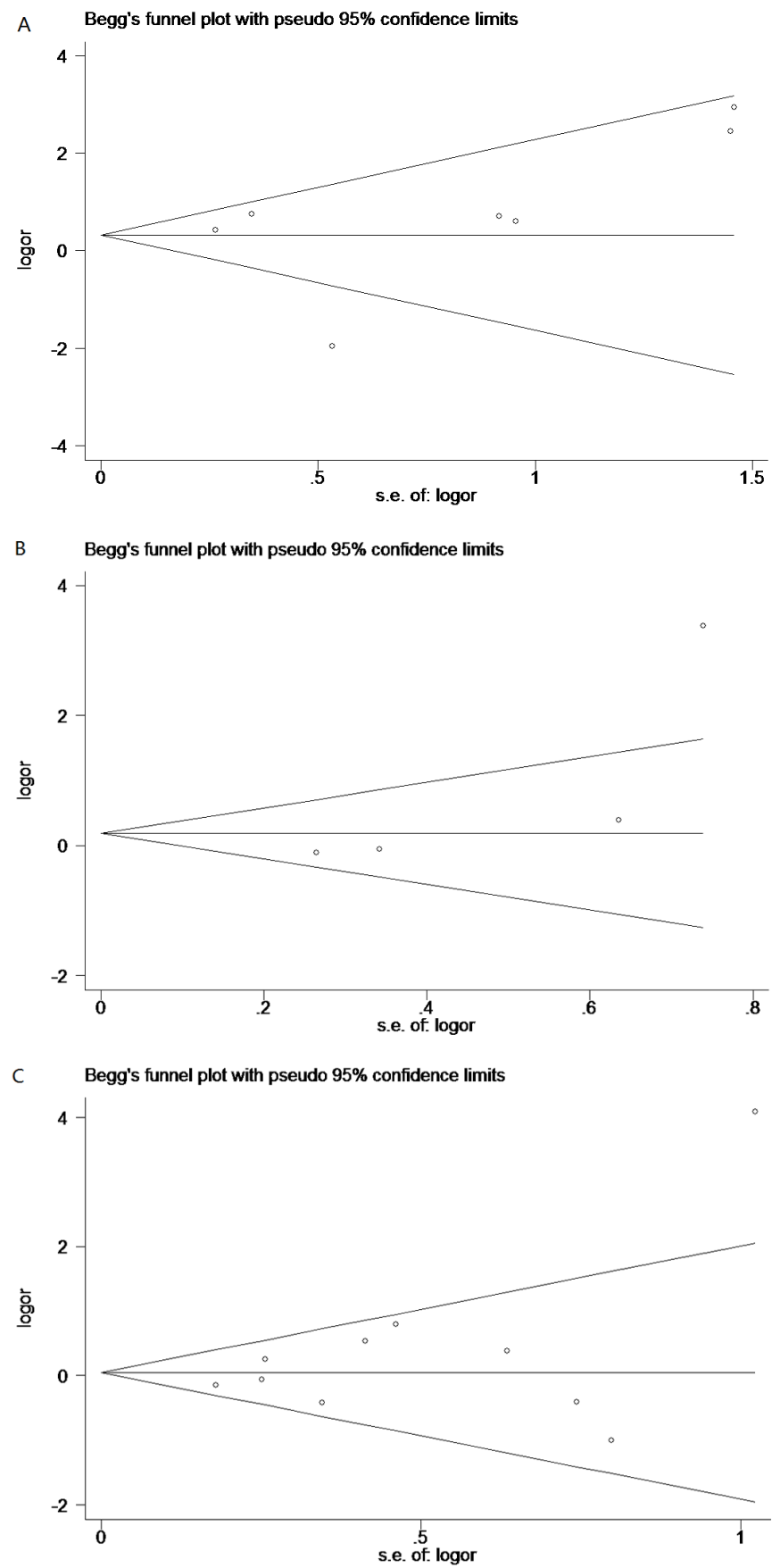

Figure 5. A. Funnel plot of the $I L-10-1082 \mathrm{G} / \mathrm{A}$ polymorphism under a dominant model B. Funnel plot of the $I L-$ $10-819 \mathrm{C} / \mathrm{T}$ polymorphism under a dominant model C. Funnel plot of the $I L-10-592 \mathrm{C} / \mathrm{A}$ polymorphism under a dominant model (each point represents a separate study for the indicated association). 


\section{Quantitative analysis of the -819C/T polymorphism}

We investigated the correlation between the $I L-10-819 \mathrm{C} / \mathrm{T}$ polymorphism and asthma risk in children based on the results obtained by five studies comprising 790 cases and 656 controls. No significant heterogeneity was observed in the $I^{2}=0.0 \%, \mathrm{P}=0.997$ ) and recessive $\left(I^{2}=32.9 \%, \mathrm{P}=0.215\right)$ models. However, marked heterogeneity was observed in the dominant $\left(I^{2}=87.3 \%, \mathrm{P}<0.001\right)$ and allelic models $\left(I^{2}=69.2 \%, \mathrm{P}=0.011\right)$. There was no evidence of an association between the $I L-10-819 \mathrm{C} / \mathrm{T}$ polymorphism and pediatric asthma risk in any of the genetic models in the overall population (allelic model: $\mathrm{OR}=1.146,95 \% \mathrm{CI}=0.835-1.574, \mathrm{P}$ $=0.398$; additive model: $\mathrm{OR}=0.908,95 \% \mathrm{CI}=0.603-1.366, \mathrm{P}=0.643$; recessive model: $\mathrm{OR}=$ $0.871,95 \% \mathrm{CI}=0.604-1.257, \mathrm{P}=0.461$; dominant model: $\mathrm{OR}=2.119,95 \% \mathrm{CI}=0.637-7.047$, $\mathrm{P}=0.221$ ). The results of these analyses are shown in Table 5 and Figure 6. Only five studies conducted in Asian populations were included in this meta-analysis; therefore, a subgroup analysis was not performed. The result of the one-way sensitivity analysis indicated that the results were stable (Figure $4 \mathrm{~B}$ ).

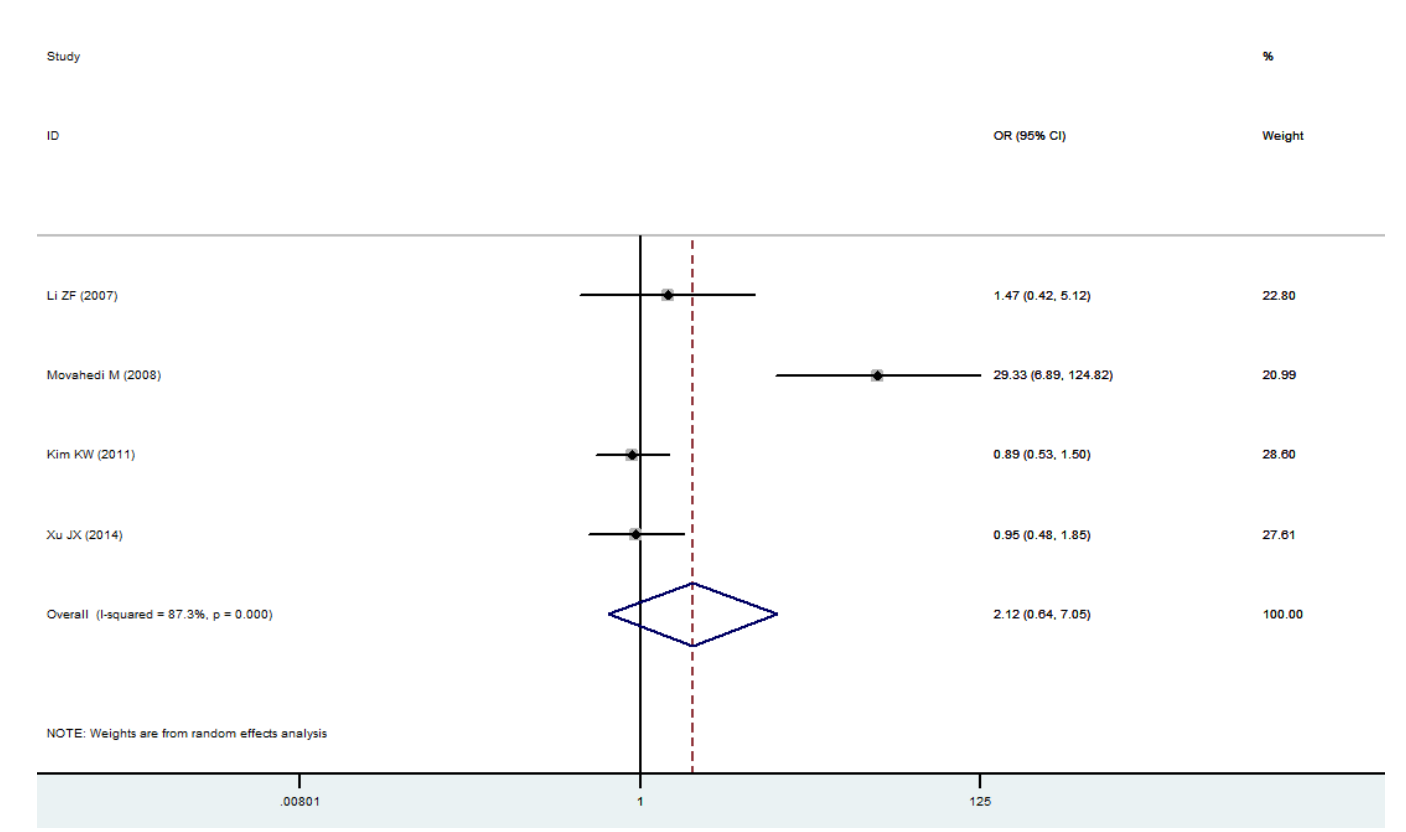

Figure 6. Forest plot of the $I L-10-819 \mathrm{C} / \mathrm{T}$ polymorphism under a dominant genetic model.

No evidence of publication bias was found in any of the genetic model comparisons, except the recessive model (Egger's test: $\mathrm{P}=0.625,0.911,0.912$, and 0.020 for the allelic model, additive, dominant, and recessive models, respectively) (Figure 5B).

\section{Quantitative analysis of the -592C/A polymorphism}

Ten studies, comprising 1480 cases and 1462 controls, included in this meta-analysis evaluated the relationship between $I L-10-592 \mathrm{C} / \mathrm{A}$ polymorphism and pediatric asthma risk. 
The -592A allele was observed at a frequency of 61.62 and $24.51 \%$ in Asian and non-Asian populations, respectively. Table 5 and Figure 7 show the results of the association between the $-592 \mathrm{C} / \mathrm{A}$ polymorphism and pediatric asthma. In the pooled analysis, we observed no significant association under a dominant model $(\mathrm{OR}=1.211,95 \% \mathrm{CI}=0.786-1.865, \mathrm{P}=$ 0.386 ); this was also observed in the other comparative models (allelic model: $\mathrm{OR}=1.123$, $95 \% \mathrm{CI}=0.574-2.637, \mathrm{P}=0.327$; additive model: $\mathrm{OR}=1.044,95 \% \mathrm{CI}=0.803-1.357, \mathrm{P}=$ 0.747 ; recessive model: $\mathrm{OR}=0.986,95 \% \mathrm{CI}=0.740-1.314, \mathrm{P}=0.922$ ).

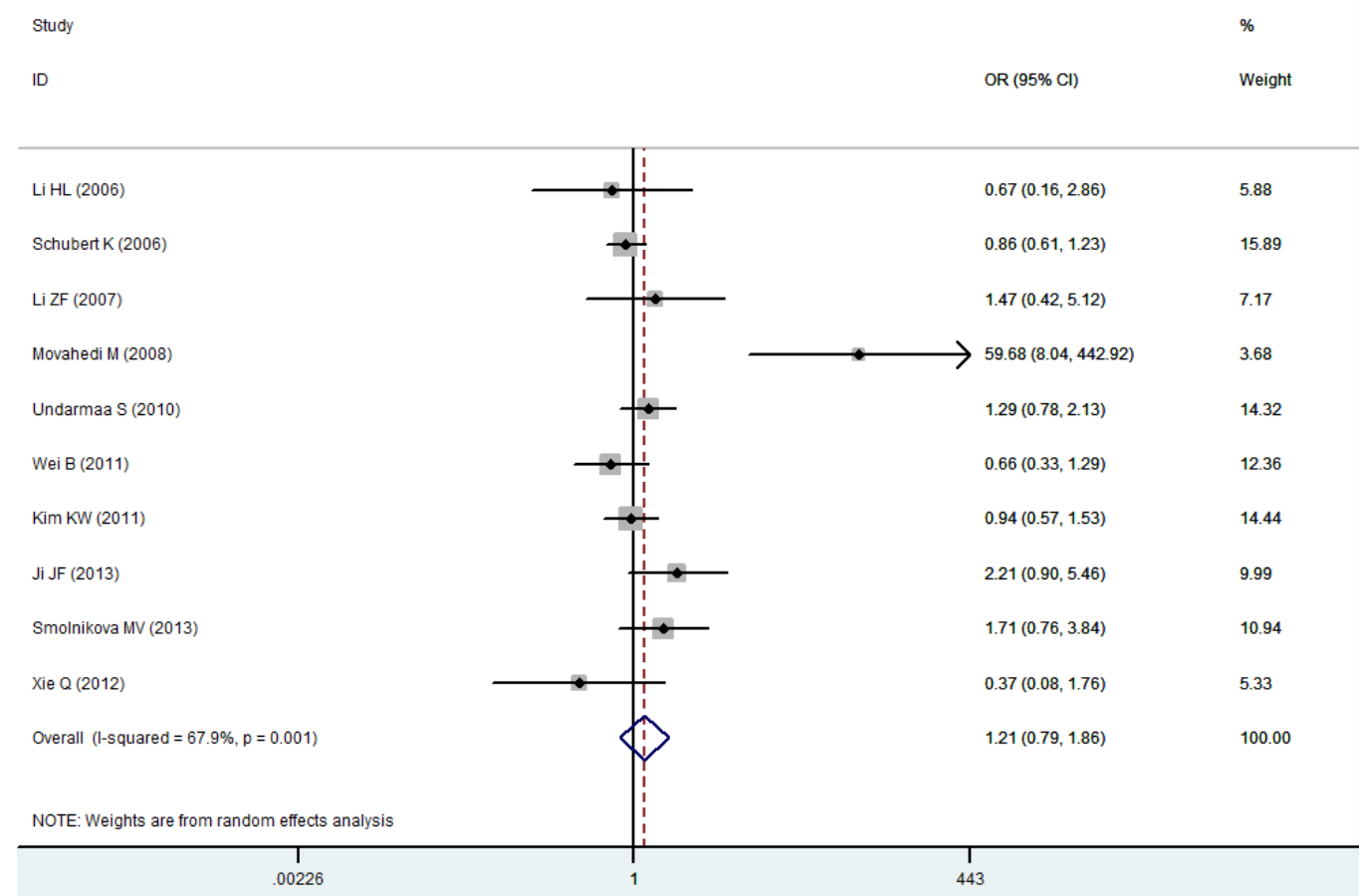

Figure 7. Forest plot of the $I L-10-592 \mathrm{C} / \mathrm{A}$ polymorphism under a dominant genetic model.

No heterogeneity was observed in the additive model $\left(I^{2}=40.5 \%, \mathrm{P}=0.088\right)$. However, marked heterogeneity existed in the allelic $\left(I^{2}=72.5 \%, \mathrm{P}<0.001\right)$, dominant $\left(I^{2}=\right.$ $67.9 \%, \mathrm{P}=0.001)$, and recessive models $\left(I^{2}=55.5 \%, \mathrm{P}=0.010\right)$. When the data was stratified based on ethnicity and atopic status, no statistically significant associations were observed in any of the subgroups. One-way sensitivity analysis was also applied to assess the stability of this meta-analysis and the results revealed that study was stable (Figure 4C).

No significant publication bias was found in any genetic model, based on the visual assessment of Begg's funnel plot (Figure 5C); this result was confirmed by Egger's test ( $\mathrm{P}=0.527$, $0.904,0.217$, and 0.544 for the allelic, additive, dominant, and recessive models, respectively).

\section{DISCUSSION}

To our knowledge, this meta-analysis is the first study to investigate the relationship between $I L-10$ promoter polymorphisms and the risk of pediatric asthma. The results of this 
study suggest that the $I L-10-1082 \mathrm{G} /$ A polymorphism may be associated with susceptibility to pediatric asthma.

Numerous studies have indicated that inflammation plays an important role in the occurrence and development of asthma. IL-10, an anti-inflammatory cytokine, inhibits the production of pro-inflammatory cytokines and displays pleiotropic effects in asthma. IL-10 expression is significantly decreased in asthmatics, suggesting an important role of IL-10 in the pathogenesis of this disease (Raeiszadeh Jahromi et al., 2014). A previous study has suggested that the secretion of IL-10 was determined largely (74\%) by heritable factors (Westendorp et al., 1997).

To date, more than one hundred risk genes have been identified as being associated with asthma susceptibility. Among these, IL-10 promoter polymorphisms have been intensively investigated. A majority of these studies have focused on three polymorphisms (-1082G/A, $-819 \mathrm{C} / \mathrm{T}$, and $-592 \mathrm{C} / \mathrm{A}$ ) located in the $I L-10$ promoter region. Growing evidence indicates that these polymorphisms may influence the secretion of IL-10. Zhang et al. (2002) reported that the C-to-T mutation at position -819 could increase the total serum IgE level by reducing the upregulation of IL-10 expression. Ji et al. (2013) concluded that individuals with the AA genotype had lower serum IL-10 levels than those with the CC genotype.

In 1999, Tagore et al. (1999) reported that patients carrying the -1082A allele or the 1082A/-819C/-592C haplotype were more likely to develop inflammatory diseases. Recent studies conducted in various countries have shown that $I L-10$ promoter polymorphisms may be associated with susceptibility to asthma. For instance, Xie (2012) suggested that the $I L$ $10-627 \mathrm{C} / \mathrm{A}$ polymorphism was associated with asthma risk in Chinese children. A study conducted in Egyptian asthmatic children showed a significantly higher frequency of the IL-10 -1082 GG genotype in these patients (Zedan et al., 2008). However, there have also been studies reporting contradictory results: Kim et al. (2011) reported that the frequency of genotypes and alleles of the $I L-10$ promoter polymorphisms $(-1082 \mathrm{G} / \mathrm{A},-819 \mathrm{C} / \mathrm{T}$, and $-592 \mathrm{C} /$ A) did not differ significantly between Korean asthmatic children and controls.

In this meta-analysis, we investigated the association between the $I L-10$ promoter polymorphisms and pediatric asthma in 16 studies comprising 2494 cases and 2160 controls. The overall population showed no significant association between the $I L-10-1082 \mathrm{G} / \mathrm{A}$ polymorphism and pediatric asthma. The significant heterogeneity between studies also mandated subgroup analyses based on the ethnicity of the study populations and the atopic status of the disease. In the subgroup analysis by ethnicity, significant associations were found among Asians under a dominant model $(\mathrm{OR}=3.607,95 \% \mathrm{CI}=1.141-11.407, \mathrm{P}=0.029)$ and among Africans under a recessive model $(\mathrm{OR}=2.429,95 \% \mathrm{CI}=1.620-3.642, \mathrm{P}<0.001)$. When stratified by the atopic status, we found significant associations among atopic asthmatics in a recessive model $(\mathrm{OR}=1.926,95 \% \mathrm{CI}=1.167-3.179, \mathrm{P}=0.010)$ and among non-atopic asthmatics in an additive $(\mathrm{OR}=2.342,95 \% \mathrm{CI}=1.222-4.487, \mathrm{P}=0.010)$ and allelic model $(\mathrm{OR}=1.416,95 \% \mathrm{CI}=1.033-1.941, \mathrm{P}=0.031)$. However, as a small number of subjects were included in the subgroup analysis, the results should be interpreted with caution.

We found no evidence of a significant association between the $-819 \mathrm{C} / \mathrm{T}$ and $-592 \mathrm{C} / \mathrm{A}$ polymorphisms and pediatric asthma in our study. The results of the subgroup analyses were also concurrent with this conclusion.

So far, three meta-analyses have been conducted to investigate the correlation between $I L-10$ polymorphisms and asthma susceptibility. These meta-analyses demonstrated that the $I L-10$ promoter polymorphisms were not associated with pediatric asthma risk. However, 
these studies had some limitations: the focus of these studies was whole asthma populations, and not children alone and a very small number of studies conducted specifically in children were included in these analyses. The results of our study were found to be inconsistent with the results of these meta-analyses. The differences in statistical power may be one reason for the discrepancy in the results. Compared to the previous studies, we have performed an updated, comprehensive meta-analysis of studies analyzing the association between $I L-10$ promoter polymorphisms and pediatric asthma risk. Sixteen relevant papers were identified for our meta-analysis via a comprehensive system of retrieval, which was far more than the number of studies included in the previous analyses. Therefore, the statistical power of our analysis could be higher. We also performed a sensitivity analyses to determine the stability of the study. Additionally, heterogeneity analysis and subgroup analyses were performed to investigate the sources of heterogeneity; this was one of the highlights of our study.

There are several limitations to this meta-analysis. Firstly, although subgroup analyses and one-way sensitivity analyses were performed, the influence of heterogeneity arising from unmeasured or unreported factors could not be completely excluded in our analysis. Secondly, only sixteen relevant articles could be identified for this meta-analysis; the relatively small size of the participants could therefore be a factor responsible for the heterogeneity. In addition, although the population was analyzed based on their ethnicity, a very small number of studies have been conducted in African $(\mathrm{N}=3)$ and Caucasian $(\mathrm{N}=2)$ populations. Therefore, the results might be over-influenced by random-errors. Therefore, well-designed and large-scale studies are required for further analyses.

In conclusion, despite the limitations, the results of this study indicated that the $I L-10$ $-1082 \mathrm{G} / \mathrm{A}$ polymorphism, and not the $-819 \mathrm{C} / \mathrm{T}$ and $-592 \mathrm{C} / \mathrm{A}$ polymorphisms, might be a risk factor for pediatric asthma. However, because of the small number of subjects included in the subgroup analyses, the results should be interpreted with caution.

\section{Conflicts of interest}

The authors declare no conflict of interest.

\section{ACKNOWLEDGMENTS}

The authors are grateful to the support provided by the Department of Pediatrics at the No. 2 Hospital of Changzhou.

\section{REFERENCES}

Bilal M, Haseeb A, Khan MH, Saad M, et al. (2016). Factors associated with patient visits to the emergency department for asthma therapy in Pakistan. Asia Pac. Fam. Med. 15: 1. http://dx.doi.org/10.1186/s12930-016-0026-y

Del Prete G, De Carli M, Almerigogna F, Giudizi MG, et al. (1993). Human IL-10 is produced by both type 1 helper (Th1) and type 2 helper (Th2) T cell clones and inhibits their antigen-specific proliferation and cytokine production. J. Immunol. 150: 353-360.

Daley D, Lemire M, Akhabir L, Chan-Yeung M, et al. (2009). Analyses of associations with asthma in four asthma population samples from Canada and Australia. Hum. Genet. 125: 445-459. http://dx.doi.org/10.1007/s00439-009-0643-8

DerSimonian R and Kacker R (2007). Random-effects model for meta-analysis of clinical trials: an update. Contemp. Clin. Trials 28: 105-114. http://dx.doi.org/10.1016/j.cct.2006.04.004

Eijkemans M, Mommers M, de Vries SI, van Buuren S, et al. (2008). Asthmatic symptoms, physical activity, and overweight in young children: a cohort study. Pediatrics 121: e666-e672. http://dx.doi.org/10.1542/peds.2007-1236 
Favarato G, Anderson HR, Atkinson R, Fuller G, et al. (2014). Traffic-related pollution and asthma prevalence in children. Quantification of associations with nitrogen dioxide. Air Qual. Atmos. Health 7: 459-466. http://dx.doi.org/10.1007/ $\underline{\text { s11869-014-0265-8 }}$

Huang ZY, Cheng BJ, Cai GJ and Zhang BF (2015). Association of the IL-4R Q576R polymorphism and asthma in the Chinese Han population: a meta-analysis. Genet. Mol. Res. 14: 2900-2911. http://dx.doi.org/10.4238/2015. March.31.21

Hussein YM, Shalaby SM, Mohamed RH and Hassan TH (2011). Association between genes encoding components of the IL-10/IL-0 receptor pathway and asthma in children. Ann. Allergy Asthma Immunol. 106: 474-480. http://dx.doi. org/10.1016/j.anai.2011.02.021

Hussein YM, Alzahrani SS, Alharthi AA, Ghonaim MM, et al. (2014). Association of serum cytokines levels, interleukin $10-1082 \mathrm{G} / \mathrm{A}$ and interferon- $\gamma+874 \mathrm{~T} / \mathrm{A}$ polymorphisms with atopic asthma children from Saudi Arabia. Cell. Immunol. 289: 21-26. http://dx.doi.org/10.1016/j.cellimm.2014.03.006

Hyun MH, Lee CH, Kang MH, Park BK, et al. (2013). Interleukin-10 promoter gene polymorphisms and susceptibility to asthma: a meta-analysis. PLoS One 8: e53758. http://dx.doi.org/10.1371/journal.pone.0053758

Ji JF, Guan LX, Wang LJ, Liu CY, et al. (2013). Association of interleukin-10 gene-592C/A polymorphism with concentration of interleukin-10 in children with bronchial asthma. Clin. J. Appl. Clin. Pediatr. 28: 261-264.

Kim KW, Lee KE, Hong JY, Kim MN, et al. (2011). Involvement of IL-10 gene promoter polymorphisms in the susceptibility for childhood asthma. Lung 189: 417-423. http://dx.doi.org/10.1007/s00408-011-9312-5

Kube D, Hua TD, Klöss M, Kulle B, et al. (2007). The interleukin-10 gene promoter polymorphism -1087AG does not correlate with clinical outcome in non-Hodgkin's lymphoma. Genes Immun. 8: 164-167. http://dx.doi.org/10.1038/ sj.gene. 6364364

Li HL, Zhao XF and Huang YK (2006). A study on the association between the interleukin-10 -627(C/A) polymorphism and childhood asthma. Chin. J. Birth Health and Heredit. 14: 15-17.

Li ZF, Lu JH, Li JR and Liao BP (2007). Lack of association between childhood asthma and interleukin-10 polymorphism gene. Central Plains Med. J. 34: 4-5.

Lyon H, Lange C, Lake S, Silverman EK, et al. (2004). IL10 gene polymorphisms are associated with asthma phenotypes in children. Genet. Epidemiol. 26: 155-165. http://dx.doi.org/10.1002/gepi.10298

Moher D, Liberati A, Tetzlaff J and Altman DG; PRISMA Group (2009). Preferred reporting items for systematic reviews and meta-analyses: the PRISMA statement. Ann. Intern. Med. 151: 264-269, W64. http://dx.doi.org/10.7326/00034819-151-4-200908180-00135

Movahedi M, Mahdaviani SA, Rezaei N, Moradi B, et al. (2008). IL-10, TGF-beta, IL-2, IL-12, and IFN-gamma cytokine gene polymorphisms in asthma. J. Asthma 45: 790-794. http://dx.doi.org/10.1080/02770900802207261

Nie W, Fang Z, Li B and Xiu QY (2012). Interleukin-10 promoter polymorphisms and asthma risk: a meta-analysis. Cytokine 60: 849-855. http://dx.doi.org/10.1016/j.cyto.2012.08.023

Raeiszadeh Jahromi S, Mahesh PA, Jayaraj BS, Madhunapantula SR, et al. (2014). Serum levels of IL-10, IL-17F and IL-33 in patients with asthma: a case-control study. J. Asthma 51: 1004-1013. http://dx.doi.org/10.3109/02770903. $\underline{2014.938353}$

Schubert K, von Bonnsdorf H, Burke M, Ahlert I, et al. (2006). A comprehensive candidate gene study on bronchial asthma and juvenile idiopathic arthritis. Dis. Markers 22: 127-132. http://dx.doi.org/10.1155/2006/373620

Smolnikova MV, Smirnova SV, Freidin MB and Tyutina OS (2013). Immunological parameters and gene polymorphisms (C-590T IL4, C-597A IL10) in severe bronchial asthma in children from the Krasnoyarsk region, West Siberia. Int. J. Circumpolar Health 72: 72. http://dx.doi.org/10.3402/ijch.v72i0.21159

Tagore A, Gonsalkorale WM, Pravica V, Hajeer AH, et al. (1999). Interleukin-10 (IL-10) genotypes in inflammatory bowel disease. Tissue Antigens 54: 386-390. http://dx.doi.org/10.1034/j.1399-0039.1999.540408.x

Tan JY, Huang X, Li DX, Chen JF, et al. (2013). Association between IL-10 and IL-33 single nucleotide polymorphisms and asthma susceptibility in Han children in Zhongshan city. Guangdong Med. J. 34: 1239-1242.

Tang L, Lin HG and Chen BF (2014). Association of IL-4 promoter polymorphisms with asthma: a meta-analysis. Genet. Mol. Res. 13: 1383-1394. http://dx.doi.org/10.4238/2014.February.28.11

Tang SP, Liu YL, Wang SB, Weng SF, et al. (2015). Trends in prevalence and risk factors of childhood asthma in Fuzhou, a city in Southeastern China. J. Asthma 52: 10-15. http://dx.doi.org/10.3109/02770903.2014.952434

Undarmaa S, Mashimo Y, Hattori S, Shimojo N, et al. (2010). Replication of genetic association studies in asthma and related phenotypes. J. Hum. Genet. 55: 342-349. http://dx.doi.org/10.1038/jhg.2010.32

Wei B, Zhu LL and Deng DF (2011). Association between polymorphisms in promoter region of Interleukin-10 and Interleukin-17 gene and childhood asthma. Progress in Modern Biomed. 11: 307-313.

Westendorp RG, Langermans JA, Huizinga TW, Verweij CL, et al. (1997). Genetic influence on cytokine production in 
meningococcal disease. Lancet 349: 1912-1913. http://dx.doi.org/10.1016/S0140-6736(05)63910-4

Xie Q (2012). Study of the correlation between IL-10 gene-627C/A polymorphism and childhood asthma. Md. Med. J. 40: 51-53.

Xu JX, Shi F and Li J (2014). Polymorphisms and susceptibility to asthma in children study of Interleukin-10 gene single nucleotide. China J. Chin. Med. 29: 639-641.

Zedan M, Settin A, Farag MK, El-Bayoumi M, et al. (2008). Gene polymorphisms of tumor necrosis factor alpha-308 and interleukin-10-1082 among asthmatic Egyptian children. Allergy Asthma Proc. 29: 268-273. http://dx.doi. org/10.2500/aap.2008.29.3123

Zhai WH, Song CY, Huang ZG and Sha H (2015). Correlation between the genetic polymorphism of ORMDL3 gene and asthma risk: a meta-analysis. Genet. Mol. Res. 14: 7101-7112. http://dx.doi.org/10.4238/2015.June.29.3

Zhan X and Chen WX (2013). Study on the relationship between Interleukin-10 gene polymorphism and autoimmune disease. Lab. Med. Clin. 10: 2173-2175.

Zhang J, Chen H, Hu L, Fu J, et al. (2002). [Correlation between polymorphism of IL-4 and IL-10 gene promoter and childhood asthma and their impact upon cytokine expression]. Zhonghua Yi Xue Za Zhi (Taipei) 82: 114-118.

Zheng XQ, Li CC, Xu DP, Lin A, et al. (2010). Analysis of the plasma soluble human leukocyte antigen-G and interleukin-10 levels in childhood atopic asthma. Hum. Immunol. 71: 982-987. http://dx.doi.org/10.1016/j.humimm.2010.06.018

Zheng XY, Guan WJ, Mao C, Chen HF, et al. (2014). Interleukin-10 promoter 1082/-819/-592 polymorphisms are associated with asthma susceptibility in Asians and atopic asthma: a meta-analysis. Lung 192: 65-73. http://dx.doi. org/10.1007/s00408-013-9519-8 